\title{
Analisis Faktor-Faktor yang Mempengaruhi Keputusan Mahasiswa dalam Memilih Program Studi Manajemen Jenjang Strata-1 pada Perguruan Tinggi Swasta dan Perguruan Tinggi Negeri di Kota Jambi
}

\author{
Friska Artaria Sitanggang*, Dini Elida Putri, Prayetno Agustinus Sitanggang \\ Program Studi Manajemen, Sekolah Tinggi Ilmu Ekonomi Jambi \\ *Correspondence email: artaria888@gmail.com
}

\begin{abstract}
Abstrak. Penelitian ini bertujuan untuk menganalisis faktor-faktor yang mempengaruhi keputusan mahasiswa, dalam memilih program studi Manajemen. Sampel penelitian berjumlah 422 orang dari Perguruan Tinggi di Kota Jambi. Metode pengumpulan data dengan kuesioner, yang dianalisis menggunakan SmartPLS. Hasil penelitian menunjukkan bahwa program studi berpengaruh secara langsung terhadap citra perguruan tinggi. Program studi berpengaruh positif signifikan secara tidak langsung terhadap sikap. Citra perguruan tinggi, sosial, persepsi, dan motivasi berpengaruh secara langsung terhadap sikap. Program studi berpengaruh positif signifikan secara tidak langsung terhadap keputusan mahasiswa, melalui citra perguruan tinggi dan sikap sebagai intervening. Citra perguruan tinggi, sosial, motivasi berpengaruh positif signifikan terhadap keputusan mahasiswa melalui sikap. Sikap dan persepsi berpengaruh positif signifikan secara langsung terhadap keputusan mahasiswa. Dalam mengembangkan strategi pemasarannya, institusi perlu memperhatikan faktor-faktor yang mempengaruhi keputusan mahasiswa, meningkatkan citranya melalui program studi tanpa mengabaikan aspek lainnya, yakni dengan mengembangkan kurikulum, layanan, maupun kualitas dosen. Selain itu, institusi perlu menjaga hubungan baik dengan orang tua mahasiswa dan alumni, serta meningkatkan prestasi mahasiswa baik akademis maupun non akademis. Demikian pula motivasi mahasiswa harus ditingkatkan, untuk membentuk sikap dan persepsi positif, agar semakin kuat keputusan mahasiswa.
\end{abstract}

Kata kunci: sikap; citra perguruan tinggi; motivasi; persepsi; keputusan mahasiswa.

Abstract. This research aims to analyze factors influencing student decisions, in selecting management major. Sample of this research is 422 students from colleges in Jambi City. The data collection method is using questionnaires, analyzed using SmartPLS. The results showed that college major has a direct effect on the image of college. College major has an indirect, significant, positive effect on attitude. College's image, social, perception and motivation has a direct effect on attitude. College's major positively, significantly and indirectly affect student's decision, through college's image and attitude as an intervening variables. College's image, social, and motivation affect student's decision positively, significantly through attitude. Attitude and perception has a significant, positive, direct effect on student's decision. In developing its marketing strategy, a colege's institution needs to pay attention to factors that affecting student's decision, improving its image through major without ignoring other aspects, that is by developing its curriculum, services, and lecture's qualification. Furthermore, a college institution needs to maintain a good relationship with student's parents and alumni, as well as improving student's academic and non academics achievement. Simirlarly, student's motivation needs to be improved as to form a positive attitude and perception in order to make a profound decision.

Keywords: Attitudes; College Image; Motivation; Perception; Student Decisions

\section{PENDAHULUAN}

Setiap perguruan tinggi berperan penting dalam menghasilkan sumber daya manusia yang berkualitas dan berakhlak mulia, untuk menjawab tantangan diera Revolusi Industri 4.0. Hakekatnya masing-masing institusi harus mampu menjaga citranya, sebab informasi dalam era digital ini sangat mudah menyebar dan mempengaruhi persepsi publik. Beragam program studi yang ditawarkan oleh institusi pendidikan, salah satunya adalah Manajemen. Jumlah program studi yang dikelola oleh institusi yang menjadi objek penelitian ini, sebagai berikut:

Tabel 1

Jumlah Program Studi PTS dan PTN Kota Jambi Tahun 2020

\begin{tabular}{lll}
\hline No. & Nama Institusi & Jumlah Prodi \\
\hline 1. & Universitas Jambi (UNJA) & 98 \\
2. & Universitas Muhammadiyah Jambi (UMJ) & 5 \\
3. & Universitas Batanghari (UNBARI) & 16 \\
4. & Universitas Adiwangsa Jambi (UNAJA) & 15 \\
5. & STIE Jambi & 2 \\
\hline
\end{tabular}

Sumber: data diolah 
Friska Artaria Sitanggang, Dini Elida Putri dan Prayetno Agustinus Sitanggang, Analisis Faktor-Faktor yang Mempengaruhi Keputusan Mahasiswa dalam Memilih Program Studi Manajemen Jenjang Strata-1 pada Perguruan Tinggi Swasta dan Perguruan Tinggi Negeri Di Kota Jambi

Berdasarkan tabel diatas, untuk perguruan tinggi negeri (PTN), yang diwakili oleh Universitas Jambi, memiliki jumlah program studi yang relatif lebih banyak, jika dibandingkan dengan institusi dari perguruan tinggi swasta (PTS). Sedangkan untuk jumlah populasi penelitian berdasarkan jenis perguruan tinggi, dapat dilihat pada tabel berikut:

Tabel 2

Populasi Mahasiswa Program Studi Manajemen Kota Jambi

\begin{tabular}{|l|l|r|r|r||}
\hline \multirow{2}{*}{ No. } & Jenis & \multicolumn{2}{|c|}{ Tahun Akademik } & \multirow{2}{*}{ Tren (\%) } \\
\cline { 2 - 4 } & & $2018 / 2019$ & $2019 / 2020$ & \\
\hline 1. & PTN & 1.380 & 1.228 & -11 \\
2. & PTS & 3.285 & 4.046 & 23 \\
\hline
\end{tabular}

Sumber: data diolah

Diketahui bahwa jumlah mahasiswa program studi Manajemen Jenjang Strata-1 di Perguruan Tinggi Swasta Kota Jambi, menunjukkan tren pertumbuhan yang cenderung naik, diangka 23\%. Sementara pada Perguruan Tinggi Negeri peminat untuk program studi Manajemen relatif turun yakni 11\% dari tahun akademik 2018/2019, diduga adanya faktor-faktor yang mempengaruhi keputusan Mahasiswa dalam memilih program studi manajemen. Berdasarkan data pada tabel 1, diketahui bahwa Perguruan Tinggi Negeri (PTN) yang diwakili oleh Universitas Jambi memiliki 98 pilihan program studi, jumlah program studi dapat menjadi salah satu faktor penyebab turunnya populasi mahasiswa. Ada beragam faktor yang bisa mempengaruhi keputusan mahasiswa, baik itu dari internal maupun juga eksternal calon mahasiswa. Beragam institusi dengan program studi pilihan, menjadi alternatif bagi masyarakat atau calon mahasiswa. Institusi tersebut tersebar di seluruh wilayah Indonesia, berdasarkan data yang diperoleh dari Pangkalan Data Pendidikan Tinggi bahwa tercatat 4583 institusi perguruan tinggi dalam bentuk intitut, sekolah tinggi, universitas, politeknik, maupun akademik, yang memiliki status aktif, berada di seluruh penjuru tanah air. Hal tersebut menunjukkan tingginya tingkat persaingan institusi dengan program studi pilihan, karena setiap masyarakat memiliki perbedaan persepsi dan kebutuhan, sehingga pihak manajemen perlu mengambil kebijakan yang efektif selaras dengan visi dan misi institusi, sebab setiap institusi baik yang berbentuk swasta maupun juga negeri membutuhkan mahasiswa untuk tetap eksis dalam bidang jasa pendidikan. Dalam meningkatkan minat masyarakat terhadap program studi, pihak institusi membutuhkan kerja ekstra, adapun pengambilan kebijakan efektif dengan pendekatan marketing, dapat dilakukan berdasarkan informasi yang diperoleh melalui riset perilaku konsumen, mengarah kepada pencapaian visi dan misi institusi.

Bertolak dari pernyataan diatas, rumusan masalah penelitian ini adalah apakah faktor-faktor yang mempengaruhi keputusan mahasiswa dalam memilih program studi Manajemen melalui citra perguruan tinggi dan sikap sebagai variabel intervening?. Dengan tujuan penelitian, mengetahui faktor-faktor yang mempengaruhi keputusan mahasiswa dalam memilih program studi Manajemen. Penelitian ini relevan untuk diimplementasikan mengingat peningkatan kuantitas serta kualitas mahasiswa menjadi tantangan klasik pada setiap institusi, dimana sudah banyaknya pilihan program studi yang ditawarkan oleh masing-masing institusi. Hal yang membedakan penelitian ini dengan penelitian-penelitian sebelumnya adalah terletak pada tempat, waktu, alat analisa yang digunakan, serta variabel intervening yang memediasi keputusan mahasiswa, yakni sikap dan citra perguruan tinggi.

\section{Proses Pengambilan Keputusan Mahasiswa}

Serangkaian informasi yang diterima oleh calon mahasiswa melalui proses psikologi dalam tahapan proses pengambilan keputusan. Pertama, pengenalan masalah (motivasi); kedua, pencarian informasi (persepsi); ketiga, evaluasi alternatif (sikap); keempat keputusan mahasiswa (integrasi); kelima, tahapan evaluasi purnabeli (belajar). Pada tahap kelima, mahasiswa memberikan umpan balik atas produk atau layanan yang telah diterima (Hasan, 2013).

\section{Faktor-Faktor Keputusan Mahasiswa}

Menurut Nitisusastro (2012), bahwa faktor-faktor penentu yang mempengaruhi perilaku konsumen (keputusan mahasiswa), digolongkan menjadi; pertama, faktor eksternal meliputi: sub faktor sosial budaya yang terkait dengan kehidupan masyarakat, namun tidak terkait dengan upaya pemasar, seperti; keluarga, budaya, demografi, kelas sosial, kelompok referensi, serta dinamika lingkungan disekitar konsumen, berupa upaya pemasar; kedua, faktor internal psikologis, yakni; persepsi, motivasi, sikap, kepribadian, dan pembelajaran.

\section{Hipotesis}

Hipotesis yang dibangun di dalam penelitian ini yaitu :

H1: Program Studi berpengaruh positif signifikan terhadap citra perguruan tinggi. 
Friska Artaria Sitanggang, Dini Elida Putri dan Prayetno Agustinus Sitanggang, Analisis Faktor-Faktor yang Mempengaruhi Keputusan Mahasiswa dalam Memilih Program Studi Manajemen Jenjang Strata-1 pada Perguruan Tinggi Swasta dan Perguruan Tinggi Negeri Di Kota Jambi

H2: Program Studi berpengaruh positif signifikan terhadap keputusan mahasiswa melalui citra perguruan tinggi dan sikap.

H3: Program Studi berpengaruh positif signifikan terhadap sikap melalui citra perguruan tinggi

H4: Sarana Prasarana berpengaruh positif signifikan terhadap citra perguruan tinggi

H5: Sarana Prasarana berpengaruh positif signifikan terhadap keputusan mahasiswa melalui sikap dan citra perguruan tinggi.

H6: Sarana prasarana berpengaruh positif signifikan terhadap sikap melalui citra perguruan tinggi

H7: Biaya berpengaruh positif signifikan terhadap citra perguruan tinggi

H8:Biaya berpengaruh positif signifikan terhadap keputusan mahasiswa melalui citra perguruan tinggi dan sikap.

H9: Biaya berpengaruh positif signifikan terhadap sikap melalui citra perguruan tinggi.

H10:Promosi berpengaruh positif signifikan terhadap citra perguruan tinggi

H11:Promosi berpengaruh positif signifikan terhadap keputusan mahasiswa melalui citra perguruan tinggi dan sikap.

H12:Promosi berpengaruh positif signifikan terhadap sikap melalui citra perguruan tinggi

H13:Lokasi berpengaruh positif signifikan terhadap citra perguruan tinggi

H14:Lokasi berpengaruh positif signifikan terhadap keputusan mahasiswa melalui citra perguruan tinggi dan sikap.

H15:lokasi berpengaruh positif signifikan terhadap sikap melalui citra perguruan tinggi.

H16:Latar belakang ekonomi berpengaruh positif signifikan terhadap sikap.

H17:Latar belakang ekonomi berpengaruh positif signifikan terhadap keputusan mahasiswa melalui citra perguruan tinggi dan sikap.

H1 8:Sosial berpengaruh positif signifikan terhadap sikap.

H19:Sosial berpengaruh positif signifikan terhadap keputusan mahasiswa melalui sikap.

H20:Motivasi berpengaruh positif signifikan terhadap sikap.

H21:Motivasi berpengaruh positif signifikan terhadap keputusan mahasiswa melalui sikap.

H22:Persepsi berpengaruh positif signifikan terhadap sikap.

H23:Persepsi berpengaruh positif signifikan terhadap keputusan mahasiswa.

$\mathrm{H} 24$ :citra perguruan tinggi berpengaruh positif signifikan terhadap sikap

$\mathrm{H} 25$ :citra perguruan tinggi berpengaruh positif signifikan terhadap keputusan mahasiswa melalui sikap.

H26:Sikap berpengaruh positif signifikan terhadap keputusan mahasiswa.

\section{METODE}

Penelitian ini dilaksanakan pada Tahun 2020, dengan populasi adalah seluruh mahasiswa Program Studi Manajemen dari institusi perguruan tinggi baik swasta maupun negeri di Kota Jambi, yang berada dibawah naungan Kemenristekdikti, yakni; Universitas Jambi, Universitas Batanghari, Universitas Adhiwangsa Jambi, Universitas Muhammadiyah Jambi, dan Sekolah Tinggi Ilmu Ekonomi Jambi. Jumlah sampel penelitian 422 orang Mahasiswa, relevan dengan pernyataan Sarwono (2010) yang menyatakan bahwa ukuran sampel yang ideal dalam SEM berkisar antara 200-400 responden, jika ingin output yang dihasilkan semakin tepat ukuran sampel sebaiknya lebih dari 400 responden. Metode dan instrumen pengumpulan data, yakni dengan kuesioner. Teknik penarikan sampel yang digunakan adalah purposive sampling, menurut Sugiyono, 2011:85 (dalam Miauw, 2016), bahwa teknik ini merupakan teknik penentuan sampel dengan pertimbangan tertentu. Pengolahan data dilakukan dengan menggunakan software SmartPLS 2.0 M3. Jogiyanto, 2011:69 (dalam Hamid, 2019), menyatakan dua tahapan evaluasi model pengukuran yang digunakan, yaitu model pengujian outer dan inner model.

\section{HASIL DAN PEMBAHASAN}

Berdasarkan data demografi, terdapat beragam karakteristik responden dalam penelitian ini, dimana sebanyak $38 \%$ responden berjenis kelamin pria, dan $62 \%$ responden berjenis kelamin wanita. Dengan rentang usia dibawah 20 tahun sebanyak 22\%, usia responden diantara 20-29 tahun 68\%, dan minoritas usia diantara 30-39 tahun serta rentang usia diatas 40 tahun, masing-masing $6 \%$ dan $4 \%$. Berdasarkan asal perguruan tinggi, responden yang berasal dari Universitas Jambi sebanyak 42\%, Responden dari Universitas Muhammadiyah sebesar 10\%, responden dari Universitas Batanghari sebanyak 21\%, responden dari Universitas Adiwangsa Jambi sebanyak 3\%, dan 24\% responden berasal dari Sekolah Tinggi Ilmu Ekonomi Jambi. Berdasarkan status sosial responden, diketahui bahwa $84 \%$ responden berstatus murni mahasiswa atau belum bekerja, $8 \%$ berstatus mahasiswa sembari bekerja pada Instansi Swasta/ BUMN, $4 \%$ berstatus mahasiswa yang juga bekerja pada Instansi Pemerintah, sebanyak 1\% pegawai honorer pada instansi pemerintah, dan sebanyak $3 \%$ berstatus mahasiswa sambil berwiraswasta. Selanjutnya, diketahui bahwa sebanyak $23 \%$ responden penerima beasiswa, dan $77 \%$ belum menerima beasiswa. 
Friska Artaria Sitanggang, Dini Elida Putri dan Prayetno Agustinus Sitanggang, Analisis Faktor-Faktor yang Mempengaruhi Keputusan Mahasiswa dalam Memilih Program Studi Manajemen Jenjang Strata-1 pada Perguruan Tinggi Swasta dan Perguruan Tinggi Negeri Di Kota Jambi

Tabel 3

Data Demografi Responden

\begin{tabular}{|c|c|c|c|}
\hline No. & Keterangan & Total & $\%$ \\
\hline \multirow[t]{3}{*}{1.} & Jenis Kelamin : & & \\
\hline & a. Pria & 159 & 38 \\
\hline & b. Wanita & 263 & 62 \\
\hline \multirow[t]{5}{*}{2.} & Usia : & & \\
\hline & a. dibawah 20 tahun & 91 & 22 \\
\hline & b. $20-29$ tahun & 288 & 68 \\
\hline & c. $30-39$ tahun & 27 & 6 \\
\hline & d. diatas 40 tahun & 16 & 4 \\
\hline \multirow[t]{6}{*}{3.} & Asal Perguruan Tinggi : & & \\
\hline & a. Universitas Jambi & 176 & 42 \\
\hline & b. UMJ & 43 & 10 \\
\hline & c. UNBARI & 87 & 21 \\
\hline & d. UNAJA & 13 & 3 \\
\hline & e. STIE Jambi & 103 & 24 \\
\hline \multirow[t]{6}{*}{4.} & Pekerjaan Responden: & & \\
\hline & a. belum bekerja & 356 & 84 \\
\hline & b. pegawai swasta/ BUMN & 32 & 8 \\
\hline & c. PNS/ TNI/ POLRI & 16 & 4 \\
\hline & d. honorer & 4 & 1 \\
\hline & e. wiraswasta & 14 & 3 \\
\hline \multirow[t]{3}{*}{5.} & Penerima Beasiswa : & & \\
\hline & a ya & 99 & 23 \\
\hline & b. tidak & 323 & 77 \\
\hline
\end{tabular}

Sumber: data diolah

Tabel 3 tanggapan responden, diketahui: Rata-rata tanggapan mahasiswa terhadap faktor-faktor yang mendukung keputusan seperti program studi sebesar 3,7 (setuju); biaya sebesar 3,9 (setuju); sarana prasarana sebesar 3,7 (setuju); lokasi sebesar 3,9 (setuju); promosi sebesar 3,7 (setuju); sosial sebesar 3,8 (setuju); latar belakang ekonomi sebesar 3,7 (setuju); citra perguruan tinggi sebesar 4,1 (setuju); motivasi sebesar 4,5 (sangat setuju); persepsi 4 (setuju); sikap sebesar 4,3 (sangat setuju); dan keputusan mahasiswa sebesar 4,3 (sangat setuju).

Tabel 4

Tanggapan Responden terhadap Variabel Konstruk Penelitian

\begin{tabular}{|c|c|c|c|c|c|c|c|}
\hline \multirow{2}{*}{ Variabel } & \multicolumn{5}{|c|}{ Rata-rata Keseluruhan Pilihan Jaw aban (\%) } & \multirow[b]{2}{*}{ Mean } & \multirow{2}{*}{ Kesimpulan } \\
\hline & 1 & 2 & 3 & 4 & 5 & & \\
\hline Program Studi & 0,07 & 1 & 16 & 45 & 38 & 4,2 & setuju \\
\hline Sarana Prasarana & 3 & 7 & 30 & 36 & 23 & 3,7 & setuju \\
\hline Biaya & 2 & 5 & 25 & 33 & 35 & 3,9 & setuju \\
\hline Lokasi & 3 & 6 & 25 & 33 & 33 & 3,9 & setuju \\
\hline Promosi & 2 & 9 & 29 & 35 & 25 & 3,7 & setuju \\
\hline Sosial & 3 & 8 & 24 & 30 & 35 & 3,8 & setuju \\
\hline Latar Belakang Ekonomi & 4 & 9 & 29 & 32 & 27 & 3,7 & setuju \\
\hline Citra Perguruan Tinggi & 0 & 2 & 18 & 42 & 37 & 4,1 & setuju \\
\hline Motivasi & 0 & 1 & 9 & 34 & 56 & 4,5 & sangat setuju \\
\hline Persepsi & 0 & 1 & 24 & 45 & 31 & 4 & setuju \\
\hline Sikap & 0 & 0,4 & 14 & 41 & 45 & 4,3 & sangat setuju \\
\hline Keputusan Mahasiswa & 0 & 1 & 13 & 39 & 48 & 4,3 & sangat setuju \\
\hline
\end{tabular}

Sumber: data diolah

\section{Model Pengukuran (OUTER MODEL) Uji Validitas Konvergen}

Uji validitas indikator reflektif dengan menggunakan Software SmartPLS Ghozali dan Latan,2015 (Hamid dan Suhardi, 2019:42), dapat dilihat dari nilai loading faktor untuk tiap indikator konstruk. prinsip dasar untuk menilai validitas konvergen adalah antara 0,6-0,7 untuk penelitian yang bersifat exploratory. Dari hasil pengujian diketahui ada 2 indikator yang memiliki nilai loading factor <0,6 yakni sosial1 dan biaya 1, sehingga harus didrop. Dan menghasilkan output sebagaimana ditunjukkan pada Gambar 2. Selain itu validitas konvergen, dapat diuji dengan melihat nilai AVE. Tabel dibawah menunjukkan nilai terendah AVE untuk konstruk sosial yakni sebesar 0,57, sementara nilai konstruk tertinggi adalah motivasi sebesar 0,74. Prinsip dasar nilai AVE yakni >0,5, semua variabel laten dinyatakan valid secara konvergen sehingga dapat mewakili indikator-indikator dalam bloknya. 
Friska Artaria Sitanggang, Dini Elida Putri dan Prayetno Agustinus Sitanggang, Analisis Faktor-Faktor yang Mempengaruhi Keputusan Mahasiswa dalam Memilih Program Studi Manajemen Jenjang Strata-1 pada Perguruan Tinggi Swasta dan Perguruan Tinggi Negeri Di Kota Jambi

Tabel 5

Nilai AVE, Redundancy, dan Communality

Sumber: data diolah

\begin{tabular}{||l|r|r|r|}
\hline \multicolumn{1}{|c|}{ Konstruk } & Ave & Redundancy & Commumality \\
\hline biaya & 0.60 & & 0.60 \\
\hline citra & 0.60 & 0.053 & 0.60 \\
\hline keputusan mahasiswa & 0.70 & 0.125 & 0.70 \\
\hline ekonomi & 0.64 & & 0.64 \\
\hline 1okasi & 0.64 & & 0.64 \\
\hline motivasi & 0.74 & & 0.74 \\
\hline persepsi & 0.70 & & 0.70 \\
\hline program studi & 0.63 & & 0.63 \\
\hline promosi & 0.65 & & 0.65 \\
\hline sarana prasarana & 0.72 & & 0.72 \\
\hline sikap & 0.64 & 0.176 & 0.64 \\
\hline sosia1 & 0.57 & & 0.57 \\
\hline
\end{tabular}

Koefisien redundancy variabel konstruk endogen bernilai positif dan bebas dari pengulangan data dalam permodelan. Sedangkan nilai komunalitas yang mendekati 1 , mengindikasikan bahwa indikator pada sebuah variabel laten dapat menjelaskan variabel laten dalam bloknya.

\section{Uji Validitas Diskriminan}

Menurut Jogiyanto, 2011:71 (Hamid dan Suhardi, 2019), prinsip validitas diskriminan bahwa antar konstruk yang berbeda tidak memiliki korelasi yang tinggi. Berdasarkan pengujian validitas diskriminan yang telah dilakukan, ditunjukkan pada tabel cross loading bahwa nilai seluruh indikator dalam permodelan dinyatakan valid, karena nilai loading faktor asal lebih tinggi dibandingkan nilai loading faktor yang dituju. Dari hasil pengujian cross loading dapat dilihat bahwa korelasi antara indikator (manifest) sikap1 sebesar 0,83 , nilainya lebih tinggi jika dibandingkan dengan variabel laten biaya $(0,44)$, citra $(0,63)$, keputusan $(0,73)$, ekonomi $(0,30)$, lokasi $(0,50)$, motivasi $(0,69)$, persepsi $(0,62)$, prodi $(0,64)$, promosi $(0,47)$, sarana $(0,47)$,dan variabel laten sosial $(0,52)$. Dengan demikian indikator sikap1 sudah valid secara konvergen. Demikian pula korelasi yang ditunjukkan oleh indikator dengan konstruk variabel laten lainnya. Pengujian model Part Least Square juga dilakukan dengan menguji nilai Relevansi Prediktif (Q2), yang menggambarkan bahwa data hasil pengamatan sudah direkonstruksi dengan baik, sehingga model penelitian memiliki relevansi prediktif (Sarwono \& Narimawati, 2020:16).

Perhitungan Q2, sebagai berikut:

$\mathrm{Q} 2$ relevansi prediktif $=1-(1-\mathrm{R} 21)(1-\mathrm{R} 22)(1-\mathrm{R} 23)=1-(1-0,77)(1-0,75)(1-0,70=0,98$

Besaran Q Square memiliki rentang $0<\mathrm{Q} 2<1$, dan nilai $0,98>0$ yang mendekati nilai 1 , karena mampu mencerminkan kondisi di lapangan maka dinyatakan bahwa model struktural fit. Nilai Q-square 0,98 menunjukkan bahwa model sangat baik, karena mampu menjelaskan keputusan mahasiswa sebesar $98 \%$ sedangkan sisanya $0,2 \%$ dijelaskan oleh variabel lain yang tidak diteliti.

\section{Uji Reliabilitas}

Ghozali dan Latan, 2015:75 (dalam Hamid dan Suhardi, 2019) Selain uji validitas, juga dilakukan uji reliabilitas. Mengukur reliabilitas konstruk dengan indikator reflektif dapat dilakukan dengan Cronbach"s Alpha dan Composite Reliability, dengan prinsip reliabilitas komposit harus lebih besar dari 0,70. Dari tabel dibawah terlihat bahwa semua konstuk dalam penelitian memiliki nilai reliabilitas komposit yang lebih besar dari aturan 0,7 , artinya seluruh konstruk dinyatakan reliabel.

Tabel 6

Cronbachs Alpha, Composite reliability, dan R Square

\begin{tabular}{|l|r|r|r||}
\hline \multicolumn{1}{|c|}{ Variabel } & Cronbachs Alpha & Composite Reability & R Square \\
\hline biaya & 0.89 & 0.91 & \\
\hline citra perguruan tinggi & 0.90 & 0.92 & 0.75 \\
\hline keputusan mahasiswa & 0.91 & 0.93 & 0.70 \\
\hline ekonomi & 0.89 & 0.91 & \\
\hline lokasi & 0.91 & 0.93 & \\
\hline motivasi & 0.93 & 0.94 & \\
\hline persepsi & 0.91 & 0.93 & \\
\hline program studi & 0.90 & 0.92 & \\
promosi & 0.91 & 0.93 & \\
\hline sarana prasarana & 0.94 & 0.952 & \\
sikap & 0.92 & 0.93 & 0.77 \\
\hline sosial & 0.87 & 0.90 & \\
\hline
\end{tabular}

Sumber: data diolah 
Friska Artaria Sitanggang, Dini Elida Putri dan Prayetno Agustinus Sitanggang, Analisis Faktor-Faktor yang Mempengaruhi Keputusan Mahasiswa dalam Memilih Program Studi Manajemen Jenjang Strata-1 pada Perguruan Tinggi Swasta dan Perguruan Tinggi Negeri Di Kota Jambi

Berdasarkan informasi yang disajikan pada Tabel 6 diatas, diketahui bahwa nilai alpha untuk seluruh konstruk variabel laten memiliki reliabilitas yang ideal, karena memiliki nilai diatas 0,6. Nilai cronbachs alpha yang valid, mendukung nilai reliabilitas komposit dalam menjelaskan bahwa seluruh konstruk dalam penelitian telah reliabel.

\section{Pengujian Model Struktural (Inner Model)}

Setelah melalui tahapan pengujian validitas dan reliabilitas data, maka tahapan selanjutnya yakni uji model struktural, beberapa komponen yang menjadi kriteria dalam penilaian model struktural, sebagaimana digambarkan pada tabel diatas. Goodness of fit model diukur menggunakan R-square variabel laten. Chin, 1998 (dalam Sarwono dan Narimawati, 2020:16) mengklasifikasi kriteria nilai R Square dalam tiga kategori, dan nilai R-Square pada riset ini termasuk kedalam jenis korelasi yang kuat, karena $>0,70$ sebagaimana yang ditunjukkan pada tabel diatas. Selanjutnya, kriteria penilaian model sruktural tahap berikutnya adalah uji signifikansi. Ghozali dan Latan, 2015:85 (Hamid dan Suhardi, 2019) menyatakan bahwa nilai signifikansi yang digunakan t-statistik 1,96 untuk level signifikan $5 \%(95 \%)$.

\section{Uji Hipotesa}

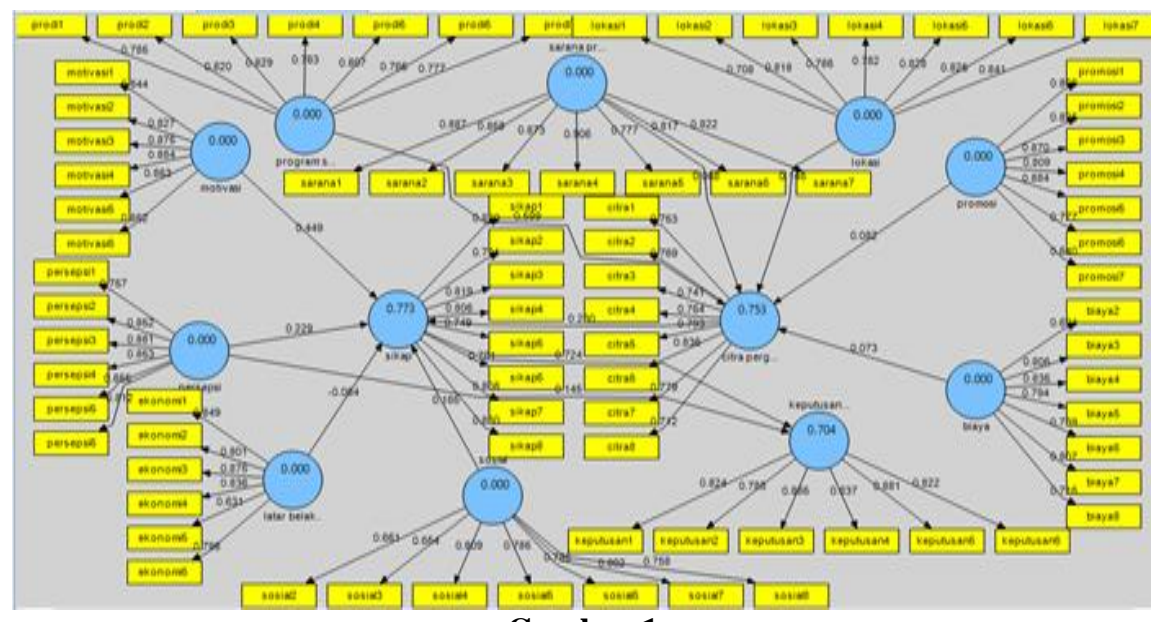

\section{Gambar 1}

Diagram Jalur Persamaan Struktural

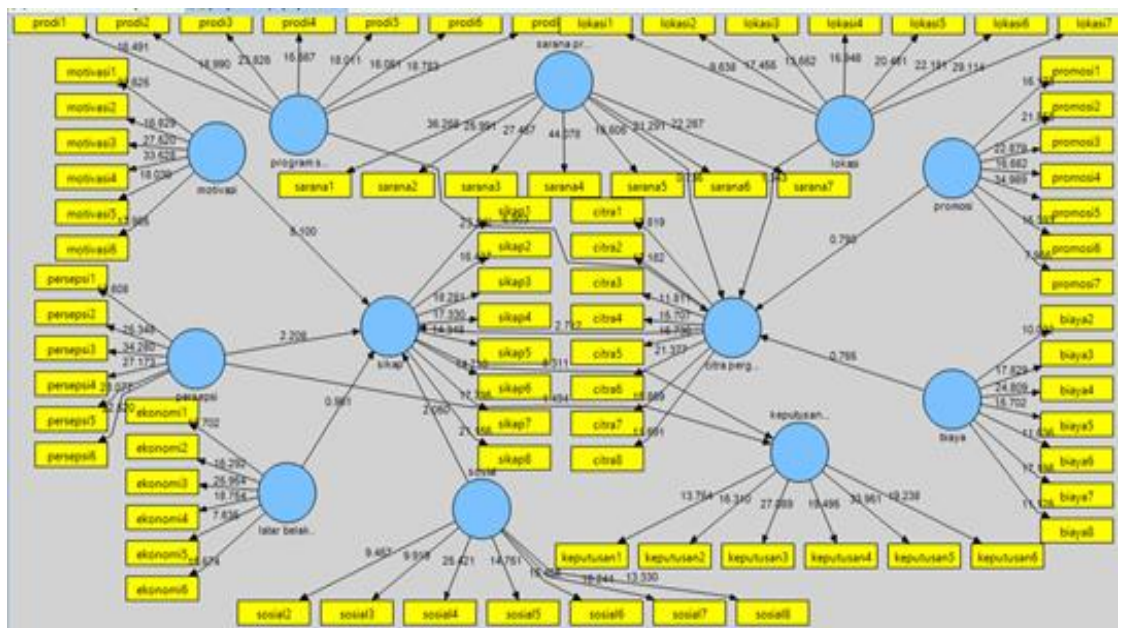

Gambar 2

Diagram Jalur Tahap Pengujian Signifikansi

Berdasarkan hasil uji hipotesa, dengan tarap signifikan 5\% (>1,96), dilakukan analisis sebagai berikut:

\section{Analisis dan Implikasi Pengaruh Program Studi Terhadap Citra Perguruan Tinggi}

Hasil pengujian diketahui bahwa nilai koefisien parameter program studi terhadap citra perguruan tinggi adalah sebesar 0,60 dengan nilai t-statistik 6,90 lebih tinggi dibandingkan t-tabel 1,96. Artinya program studi memiliki 
Friska Artaria Sitanggang, Dini Elida Putri dan Prayetno Agustinus Sitanggang, Analisis Faktor-Faktor yang Mempengaruhi Keputusan Mahasiswa dalam Memilih Program Studi Manajemen Jenjang Strata-1 pada Perguruan Tinggi Swasta dan Perguruan Tinggi Negeri Di Kota Jambi

pengaruh secara langsung dengan arah hubungan positif signifikan, sehingga hipotesis 1 diterima. Hasil temuan ini relevan dengan temuan Rudd et al., (2012), namun berbeda dengan hasil temuan Muchammad, Bima Nur (2014).Alma (2014) menyatakan bahwa produk merupakan atribut dasar dari bauran pemasaran, yang menjadi pertimbangan bagi calon mahasiswa. Pengembangan dalam aspek program studi penting untuk dilakukan, karena masyarakat sudah semakin kritis terhadap mutu dan layanan yang diberikan. Misalnya dengan peningkatan kualitas dosen, karena dosen merupakan ujung tombak dalam upaya mencapai keberhasilan pelaksanaan Tri Dharma Perguruan Tinggi. Sesuai dengan konsep yang dituangkan Alma (2014) bahwa kualitas dosen merupakan salah satu elemen yang dapat membangun citra yang baik bagi suatu institusi.

\section{Analisis dan Implikasi Pengaruh Program Studi Terhadap Keputusan Mahasiswa Melalui Citra Perguruan Tinggi dan Sikap}

Hasil pengujian diketahui bahwa nilai koefisien parameter program studi terhadap keputusan mahasiswa yang dimediasi oleh sikap dan citra perguruan tinggi adalah sebesar 0,10 dengan nilai t-statistik 2,32 lebih tinggi dibandingkan t-tabel 1,96. Artinya program studi berpengaruh positif signifikan terhadap keputusan mahasiswa, sehingga hipotesis 2 diterima. Hasil temuan ini diperkuat dengan hasil temuan Eravia (2012); Samat et al., (2018), Purwanti (2015), dan Suherman (2017). Alma (2014:383), menyatakan program studi merupakan faktor penentu yang menjadi pertimbangan bagi calon mahasiswa. Bauran produk dalam strategi pemasaran yang dimaksudkan dapat berupa diferensiasi produk, yang memberikan dampak terhadap banyaknya prospek karir, membangun citra dan positioning institusi. Implikasi dari temuan ini adalah bahwa pihak institusi, dapat mengembangkan program studi dari berbagai aspek. Purwanti (2015), menyatakan bahwa institusi yang memiliki beragam program studi, menjadi daya tarik tersendiri bagi calon mahasiswa. Selain itu dengan meningkatkan prospek karir lulusan yang tidak hanya mampu menciptakan tenaga kerja pada bidang tertentu, tetapi juga menciptakan entrepreneur guna mendukung program pemerintah, hal tersebut merujuk pada butir pernyataan intrumen, dimana rata-rata tanggapan mahasiswa bernilai 4,35, artinya responden "sangat setuju" bahwa kemampuan program studi Manajemen dalam menciptakan entrepreneur, menjadi hal yang membuat responden tertarik mengambil keputusan.

\section{Analisis dan Implikasi Pengaruh Program Studi Terhadap Sikap melalui Citra Perguruan Tinggi}

Hasil pengujian diketahui bahwa nilai koefisien parameter program studi terhadap sikap adalah sebesar 0,14 dengan nilai t-statistik 2,42 lebih tinggi dibandingkan t-tabel 1,96. Artinya program studi memiliki pengaruh terhadap sikap dengan arah positif signifikan, sehingga hipotesis 3 diterima. Hasil penelitian ini relevan dengan temuan Kirana (2015), meski dalam konsep yang berbeda, akan tetapi terdapat kesamaan pada variabel yang digunakan. Berdasarkan butir pernyataan instrumen, diketahui tanggapan rata-rata responden 4,35 (sangat setuju), menyatakan motivasi memilih program studi untuk meningkatkan ketrampilan kewirausahaan, dorongan tersebut mengarah kepada pembentukan persepsi dan sikap yang positif, sehingga memberikan implikasi kepada pihak institusi untuk mengembangkan program studinya dengan kurikulum yang mengarah kepada kewirausahaan. Hal ini relevan dengan visi dan misi perguruan tinggi pada umumnya, yang memasukkan aspek kewirausahaan, sejalan dengan program Pemerintah dalam meningkatkan jumlah entrepreneur guna menekan angka pengangguran.

Tabel 7

Total Effect, Path Coefisien, Indirect Effect

\begin{tabular}{|c|c|c|c|c|c|c|}
\hline konstruk & Total effect & Path coefisien & Indirect effect & t statistik & t tabel & $\overline{\overline{\text { Kesimpulan }}}$ \\
\hline biaya $\rightarrow$ citra & 0,07 & 0,07 & & 0,77 & 1,96 & tidak signifikan \\
\hline biaya $\rightarrow$ keputusan & 0,01 & & & 0,70 & 1,96 & tidak signifikan \\
\hline biaya $\rightarrow$ sikap & 0,02 & & & 0,71 & 1,96 & tidak signifikan \\
\hline citra $\rightarrow$ keputusan & 0,17 & & & 2,60 & 1,96 & signifikan \\
\hline citra $->$ sikap & 0,23 & 0,23 & & 2,71 & 1,96 & signifikan \\
\hline ekonomi $\rightarrow$ keputusan & $-0,05$ & & & 0,96 & 1,96 & tidak signifikan \\
\hline ekonomi $\rightarrow$ sikap & $-0,06$ & $-0,06$ & & 0,96 & 1,96 & tidak signifikan \\
\hline 1okasi -> citra & 0,15 & 0,15 & & 1,34 & 1,96 & tidak signifikan \\
\hline 1okasi $->$ keputusan & 0,02 & & & 1,16 & 1,96 & tidak signifikan \\
\hline 1okasi -> sikap & 0,03 & & & 1,16 & 1,96 & tidak signifikan \\
\hline motivasi $\rightarrow$ keputusan & 0,32 & & & 3,90 & 1,96 & signifikan \\
\hline motivasi $\rightarrow$ sikap & 0,45 & 0,45 & & 5,10 & 1,96 & signifikan \\
\hline persepsi $\rightarrow>$ keputusan & 0,31 & 0,14 & 0,17 & 2,78 & 1,96 & signifikan \\
\hline persepsi $->$ sikap & 0,23 & 0,23 & & 2,21 & 1,96 & signifikan \\
\hline prodi $->$ citra & 0,60 & 0,60 & & 6,90 & 1,96 & signifikan \\
\hline prodi $->$ keputusan & 0,10 & & & 2,32 & 1,96 & signifikan \\
\hline prodi $\rightarrow$ sikap & 0,14 & & & 2,42 & 1,96 & signifikan \\
\hline promosi $\rightarrow$ citra & 0,08 & 0,08 & & 0,79 & 1,96 & tidak signifikan \\
\hline promosi $->$ keputusan & 0,01 & & & 0,72 & 1,96 & tidak signifikan \\
\hline promosi -> sikap & 0,02 & & & 0,72 & 1,96 & tidak signifikan \\
\hline sarana $\rightarrow$ citra & 0,07 & 0,07 & & 0,74 & 1,96 & tidak signifikan \\
\hline sarana $->$ keputusan & 0,01 & & & 0,69 & 1,96 & tidak signifikan \\
\hline sarana $->$ sikap & 0,02 & & & 0,69 & 1,96 & tidak signifikan \\
\hline sikap -> keputusan & 0,72 & 0,72 & & 8,31 & 1,96 & signifikan \\
\hline sosial $\rightarrow>$ keputusan & 0,12 & & & 2,00 & 1,96 & signifikan \\
\hline sosial -> sikap & 0,17 & 0,17 & & 2,05 & 1,96 & signifikan \\
\hline
\end{tabular}

Sumber: data diolah 
Friska Artaria Sitanggang, Dini Elida Putri dan Prayetno Agustinus Sitanggang, Analisis Faktor-Faktor yang Mempengaruhi Keputusan Mahasiswa dalam Memilih Program Studi Manajemen Jenjang Strata-1 pada Perguruan Tinggi Swasta dan Perguruan Tinggi Negeri Di Kota Jambi

\section{Analisis dan Implikasi Pengaruh Sarana Prasarana Terhadap Citra Perguruan Tinggi}

Hasil pengujian diketahui bahwa nilai koefisien jalur sarana prasarana terhadap citra perguruan tinggi adalah sebesar 0,07 dan nilai t-statistik 0,74 lebih rendah dibandingkan t-tabel 1,96. Artinya sarana prasarana berpengaruh terhadap keputusan mahasiswa dengan arah positif, namun tidak signifikan sehingga hipotesis 4 ditolak. Hal tersebut berbeda dengan hasil temuan Prasetyaningrum (2016). Kendati sarana prasarana hanya memiliki pengaruh yang kecil terhadap citra perguruan tinggi, namun upaya pengembangannya harus dilakukan secara berkesinambungan, karena dapat menunjang proses penyediaan jasa Pendidikan, yang tentunya mengarah kepada meningkatnya image suatu institusi.

\section{Analisis dan Implikasi Pengaruh Sarana Prasarana Terhadap Keputusan Mahasiswa Melalui Citra Perguruan Tinggi dan Sikap.}

Hasil pengujian diketahui bahwa nilai koefisien sarana prasarana terhadap keputusan mahasiswa melalui citra perguruan tinggi dan sikap adalah sebesar 0,01 dengan nilai t-statistik 0,69 lebih rendah jika dibandingkan t-tabel 1,96. Artinya sarana prasarana memiliki pengaruh positif namun tidak signifikan terhadap keputusan mahasiswa, sehingga hipotesis 5 ditolak. Hasil temuan tersebut relevan dengan hasil temuan Samat et al.,(2018),namun berbeda dengan temuan Ismanto (2017). Russell, 2005 (dalam Rudd et al., 2012), menyatakan bahwa sarana prasarana yang disediakan oleh institusi seperti; peralatan komputer, ruang belajar yang kondusif, dan fasilitas perpustakaan, berpengaruh terhadap keputusan siswa dalam memilih suatu institusi. Arah hubungan yang linear menunjukkan bahwa semakin meningkat bukti fisik maka semakin meningkat keputusan mahasiswa. Hal tersebut mengindikasikan bahwa faktor ini tidak boleh diabaikan dalam pertimbangan strategi pemasaran, karena meskipun pengaruhnya kecil, dapat berimplikasi terhadap keputusan mahasiswa. Merujuk pada tanggapan responden terhadap faktor bukti fisik, untuk indikator terkait akses internet, rata-rata tanggapan yang diberikan responden adalah 3,37 (kurang setuju), yang mengindikasikan bahwa akses internet yang lancar menjadi salah satu daya tarik bagi mahasiswa, demikian pula dengan bukti fisik lainnya seperti bangunan, fasilitas perpustakaan, dan sebagainya. Sehingga perlunya pengembangan dalam aspek ini, sebagai upaya menarik minat calon mahasiswa.

\section{Analisis dan Implikasi Pengaruh Sarana Prasarana Terhadap Sikap Melalui Citra Perguruan Tinggi}

Hasil pengujian diketahui bahwa nilai koefisien jalur untuk sarana prasarana terhadap sikap adalah sebesar 0,02 dengan nilai t-statistik 0,96 lebih rendah dibandingkan t-tabel 1,96. Artinya sarana prasarana berpengaruh positif namun tidak signifikan keputusan mahasiswa, sehingga hipotesis 6 ditolak. Bukti fisik adalah faktor yang cukup krusial dalam bauran pemasaran jasa, menurut Zeithaml and Bitner, 2005 (Podungge dan Bachri, 2015). Kontribusi sarana prasarana terhadap pembentukan sikap positif mahasiswa juga tidak boleh diabaikan, kendatipun kecil pengaruh terhadap keputusan mahasiswa.

\section{Analisis dan Implikasi Pengaruh Biaya Terhadap Citra Perguruan Tinggi}

Hasil pengujian diketahui bahwa nilai koefisien jalur parameter biaya terhadap citra perguruan tinggi adalah sebesar 0,01 dengan nilai t-statistik 0,77 lebih rendah dibandingkan nilai t-tabel 1,96. Artinya biaya berpengaruh positif, namun tidak signifikan sehingga hipotesis 7 ditolak. Hasil temuan ini berbeda dengan temuan Prasetyaningrum (2016). Kendatipun tidak signifikan, bauran biaya tetap berpengaruh meskipun kecil, terhadap image yang dimunculkan pada sebuah perguruan tinggi. Merujuk pada butir pernyataan instrumen, dimana hasil rata-rata tanggapan 3,71 (setuju) bahwa biaya pendidikan yang dikeluarkan sesuai dengan jasa yang diterima, hal tersebut mengindikasikan bahwa mutu dan kualitas jasa harus relevan dengan biaya yang dikeluarkan, untuk memberikan image yang positif bagi masyarakat.

\section{Analisis dan Implikasi Pengaruh Biaya Terhadap Keputusan Mahasiswa Melalui Citra Perguruan Tinggi dan Sikap}

Hasil pengujian diketahui bahwa nilai koefisien jalur parameter biaya terhadap keputusan mahasiswa melalui citra perguruan tinggi dan sikap adalah sebesar 0,01 dengan nilai t-statistik 0,70 lebih rendah dibandingkan nilai ttabel 1,96. Artinya biaya berpengaruh positif namun tidak signifikan, sehingga hipotesis 8 ditolak. Hasil temuan ini relevan dengan penelitian yang dilakukan oleh Samat et al., (2018); (Muchammad, Bima Nur, 2014), namun berbeda dengan hasil penelitian Purwanti (2015). Studi yang dilakukan oleh Wilkins et al., (2013), menguji dampak dari kenaikan biaya pendidikan tinggi di Inggris terhadap proses pengambilan keputusan calon mahasiswa. Marcotte, 2008 (dalam Wilkins et al., 2013), menemukan bahwa adanya pengaruh kenaikan biaya pendidikan terhadap turunnya kuantitas calon mahasiswa yang memasuki suatu institusi. Berbeda dengan temuan dalam riset ini, sebab biaya dinyatakan linear dengan keputusan mahasiswa, artinya apabila harga meningkat akan meningkat pula keputusan mahasiswa memilih program studi, didukung oleh rata-rata tanggapan responden 3,84 (setuju) bahwa biaya 
Friska Artaria Sitanggang, Dini Elida Putri dan Prayetno Agustinus Sitanggang, Analisis Faktor-Faktor yang Mempengaruhi Keputusan Mahasiswa dalam Memilih Program Studi Manajemen Jenjang Strata-1 pada Perguruan Tinggi Swasta dan Perguruan Tinggi Negeri Di Kota Jambi

pendidikan masih relatif terjangkau. Pembayaran SPP juga dilakukan tepat waktu yakni dengan rata-rata tanggapan 4,31 (sangat setuju). Dalam hal ini, pihak institusi perlu mempertimbangkan masalah biaya pendidikan, karena meskipun pengaruhnya kecil namun apabila disesuaikan dengan kondisi mahasiswa yang berasal dari berbagai latar belakang ekonomi, serta dibantu dengan fasilitas beasiswa, keringanan, dan prosedur pembayaran yang fleksibel, tentunya dapat menarik minat calon mahasiswa.

\section{Analisis dan Implikasi Pengaruh Biaya Terhadap Sikap Melalui Citra Perguruan Tinggi}

Hasil pengujian diketahui bahwa nilai koefisien jalur parameter biaya terhadap keputusan mahasiswa, melalui variabel citra perguruan tinggi adalah sebesar 0,02 dengan nilai t-statistik 0,71 lebih rendah dibandingkan t-tabel 1,96. Artinya biaya berpengaruh dengan arah hubungan positif namun tidak signifikan, sehingga hipotesis 9 ditolak. Hasil penelitian relevan dengan temuan Suherman (2017), namun berbeda dengan hasil temuan Kusuma (2015). Alma (2014) menyatakan bahwa atribut harga yang merupakan biaya dalam jasa pendidikan, sejajar dengan mutu produk, apabila biaya pendidikan dinaikkan sepanjang masih terjangkau, tidak menurunkan minat mahasiswa untuk melanjutkan studi ke perguruan tinggi. Pernyataan tersebut relevan dengan temuan dalam riset ini yang menunjukan arah hubungan yang positif dari variabel biaya terhadap sikap mahasiswa. Artinya, apabila biaya meningkat, maka sikap mahasiswa juga meningkat, artinya kecenderungan perilaku yang mengarah kepada keputusan mahasiswa untuk memasuki suatu program studi.

\section{Analisis dan Implikasi Pengaruh Promosi terhadap citra perguruan tinggi}

Hasil pengujian diketahui bahwa nilai koefisien parameter promosi terhadap citra perguruan tinggi adalah sebesar 0,08 dengan nilai t-statistik 0,79 lebih rendah dibandingkan t-tabel 1,96. Artinya promosi berpengaruh dengan arah hubungan positif namun tidak signifikan, sehingga hipotesis 10 ditolak. Pernyataan tersebut berbeda dengan hasil temuan Prasetyaningrum (2016). Image yang baik terhadap perguruan tinggi, merupakan implikasi dari kualitas pelayanan dan kepuasan mahasiswa sebagai pengguna jasa di perguruan tinggi. Fitriani (2018), menyatakan bahwa wujud dari kepuasan yang dirasakan oleh pelanggan adalah penyampaian informasi yang positif melalui word of mouth, kepada orang lain terkait pengalamannya ketika mengkonsumsi produk maupun jasa. Menurut Sunyoto (2015), salah satu tujuan dari program promosi jasa yaitu membuat reputasi yang baik, dengan kesan positif yang diterima oleh konsumen Ketika mengkonsumsi produk maupun jasa. Reputasi terkait citra lembaga menunjukkan adanya korelasi antara citra dengan promosi, dan dalam kasus ini arah hubungan yang ditunjukkan adalah positif, artinya semakin tinggi tingkat promosi maka semakin tinggi citra perguruan tinggi, sehingga pihak manajemen juga perlu memperhatikan unsur promosi dalam kebijakan pemasarannya.

\section{Analisis dan Implikasi Pengaruh Promosi Terhadap Keputusan Mahasiswa Melalui Citra Perguruan Tinggi dan Sikap.}

Hasil pengujian diketahui bahwa nilai koefisien parameter promosi terhadap keputusan mahasiswa yang dimediasi oleh citra perguruan tinggi dan sikap adalah sebesar 0,01 dengan nilai t-statistik 0,72 lebih rendah jika dibandingkan t-tabel 1,96. Artinya promosi berpengaruh dengan arah hubungan positif namun tidak signifikan, sehingga hipotesis 11 ditolak. Temuan ini berbeda dengan temuan pada penelitian Samat et al., (2018); Erdawati (2015). Bauran promosi dilakukan dengan porsi yang sesuai kebutuhan institusi karena membutuhkan biaya dalam merealisasikannya serta mencerminkan kondisi institusi yang sesungguhnya, untuk menghindari terjadinya korelasi negatif terhadap daya tarik calon mahasiswa. Berdasarkan observasi, kuantitas pelaksanaan aktivitas promosi, lebih banyak dilakukan oleh Perguruan Tinggi Swasta yang masih lemah (Alma, 2014). Kendati pengaruh yang ditunjukkan dalam kasus ini kecil, namun pihak institusi tetap perlu mengambil strategi yang tepat dalam mempromosikan program studinya kepada masyarakat, meninjau arah hubungan yang ditunjukkan adalah positif maka artinya semakin tinggi kegiatan promosi maka akan semakin tinggi keputusan mahasiswa.

\section{Analisis dan Implikasi Pengaruh Promosi Terhadap Sikap Melalui Citra Perguruan Tinggi}

Hasil pengujian diketahui bahwa nilai koefisien parameter promosi terhadap citra perguruan tinggi adalah sebesar 0,02 dengan nilai t-statistik 0,72 lebih rendah dibandingkan t-tabel 1,96. Artinya promosi berpengaruh dengan arah hubungan positif namun tidak signifikan, sehingga hipotesis 12 ditolak. Pernyataan tersebut relevan dengan hasil temuan Muchammad Bima Nur (2014), namun berbeda dengan hasil temuan Kusuma (2015). Berdasarkan hasil survei bahwa 9\% menyatakan tidak setuju terhadap faktor promosi, hal tersebut mengindikasikan bahwa kegiatan promosi harus lebih dioptimalkan, agar informasi terkait dengan institusi dan program studi dapat dipublikasikan secara merata kepada masyarakat, karena bauran promosi turut berkontribusi terhadap pembentukan sikap calon mahasiswa dan memilihi arah hubungan yang linear, kendatipun kecil pengaruhnya. Hal tersebut mengindikasikan 
Friska Artaria Sitanggang, Dini Elida Putri dan Prayetno Agustinus Sitanggang, Analisis Faktor-Faktor yang Mempengaruhi Keputusan Mahasiswa dalam Memilih Program Studi Manajemen Jenjang Strata-1 pada Perguruan Tinggi Swasta dan Perguruan Tinggi Negeri Di Kota Jambi

bahwa, semakin tinggi tingkat promosi maka akan semakin tinggi pengaruhnya terhadap pembentukan sikap mahasiswa.

\section{Analisis dan Implikasi Pengaruh Lokasi Terhadap Citra Perguruan Tinggi}

Hasil pengujian diketahui bahwa nilai koefisien parameter lokasi terhadap citra perguruan tinggi adalah sebesar 0,15 dengan nilai t-statistik 1,34 lebih rendah jika dibandingkan t-tabel 1,96. Artinya lokasi berpengaruh dengan arah hubungan positif namun tidak signifikan, sehingga hipotesis 13 ditolak. Hasil temuan ini berbeda dengan hasil penelitian Prasetyaningrum (2016). Arah hubungan yang linear mengindikasikan bahwa, kendatipun kecil pengaruhnya jika pengembangan dalam aspek lokasi dilakukan maka akan meningkatkan citra dari sebuah perguruan tinggi.

\section{Analisis dan Implikasi Pengaruh Lokasi Terhadap Keputusan Mahasiswa Melalui Citra Perguruan Tinggi dan Sikap.}

Hasil pengujian diketahui bahwa nilai koefisien jalur parameter lokasi terhadap sikap adalah sebesar 0,02 dengan nilai t-statistik 1,16 lebih rendah dibandingkan t-tabel 1,96. Artinya lokasi berpengaruh dengan arah hubungan positif namun tidak signifikan, sehingga hipotesis 14 ditolak. Hasil temuan ini relevan dengan penelitian Samat et al., (2018), namun berbeda dengan temuan Podungge \& Bachri (2015). Arah hubungan yang positif dalam kasus ini, mengindikasikan bahwa peningkatan yang dilakukan dalam aspek lokasi seperti lingkungan yang kondusif untuk proses pembelajaran atau area parkir yang luas dan aman, tentunya akan memberikan kontribusi pada peningkatan keputusan mahasiswa. Kendatipun pengaruh yang ditunjukkan untuk aspek lokasi kecil dan tidak signifikan, pihak institusi juga perlu meningkatkan layanan dalam aspek ini. Relevan dengan teori Alma (2014), yang menyatakan bahwa Perguruan Tinggi Swasta yang letaknya strategis, diperkotaan, dan memiliki akses transportasi yang terjangkau, menjadi pertimbangan calon mahasiswa dalam proses pengambilan keputusan.

\section{Analisis dan Implikasi Pengaruh Lokasi Terhadap Sikap Melalui Citra Perguruan Tinggi}

Hasil pengujian diketahui bahwa nilai koefisien jalur parameter lokasi terhadap sikap adalah sebesar 0,03 dengan nilai t-statistik 1,16 lebih rendah dibandingkan t-tabel 1,96. Artinya lokasi berpengaruh dengan arah hubungan positif namun tidak signifikan, sehingga hipotesis 15 ditolak. Pernyataan tersebut berbeda dengan hasil temuan Kusuma, (2015). Masyarakat memiliki cara pandang yang berbeda terhadap pendidikan, ada yang berpandang bahwa cukup dengan menempuh pendidikan dalam wilayah tempat tinggalnya maka kebutuhan atas jasa pendidikan telah terpenuhi, namun adapula yang harus menempuh pendidikan diluar Provinsi Jambi yakni dengan pertimbangan tertentu. Arah hubungan yang linear terhadap sikap, mengindikasikan bahwa pengembangan dalam aspek lokasi dapat memberikan kontribusi terhadap pembentukan sikap mahasiswa, kendatipun kontribusi yang diberikan kecil karena tidak signifikan. Sehingga Pihak Manajemen juga tidak boleh mengabaikan bauran lokasi dalam strategi pemasarannya.

\section{Analisis dan Implikasi Pengaruh Latar Belakang Ekonomi Terhadap Sikap}

Abdulsyani, 2012 (Ramadhanti, Mulyadi dan Razati, 2017), menyatakan indikator yang umumnya digunakan untuk mengukur status sosial ekonomi seseorang, adalah tingkat pendidikan, tingkat pendapatan, dan profesi seseorang. Dari hasil pengujian diketahui bahwa nilai koefisien jalur parameter latar belakang ekonomi terhadap sikap adalah sebesar -0,06 dengan nilai t-statistik 0,96 lebih rendah dibandingkan t-tabel 1,96. Artinya latar belakang ekonomi berpengaruh dengan arah hubungan negatif namun tidak signifikan, sehingga hipotesis 16 ditolak. Meskipun dalam konsep yang berbeda akan tetapi variabel yang diteliti, relevan dengan penelitian Ramadhanti et al., (2017), hasil temuannya menyatakan bahwa status sosial ekonomi orang tua berpengaruh positif terhadap sikap. Artinya semakin baik sosial ekonomi seseorang, maka semakin baik pula sikap yang ditunjukkan terhadap suatu objek. Taraf perekonomian yang ditunjukkan bahwa, mayoritas mahasiswa memiliki kemampuan dalam aspek finansial, dimana tidak ditunjukkannya kendala dalam hal pembayaran jasa Pendidikan. Akan tetapi arah hubungan yang ditunjukkan dalam kasus ini adalah negatif, artinya apabila latar belakang ekonomi meningkat, maka sikap mahasiswa menurun. Hal tersebut mengindikasikan bahwa pihak institusi perlu melakukan komunikasi persuasif kepada masyarakat, akan arti pentingnya melanjutkan studi pada perguruan tinggi, karena individu dihadapkan pada berbagai pilihan dalam hidupnya.

\section{Analisis dan Implikasi Pengaruh Latar Belakang Ekonomi Terhadap Keputusan Mahasiswa Melalui Citra Perguruan Tinggi dan Sikap}

Hasil pengujian diketahui bahwa nilai koefisien parameter latar belakang ekonomi terhadap keputusan mahasiswa yang dimediasi oleh sikap adalah sebesar -0,05 dengan nilai t-statistik 0,96 lebih rendah dibandingkan t- 
Friska Artaria Sitanggang, Dini Elida Putri dan Prayetno Agustinus Sitanggang, Analisis Faktor-Faktor yang Mempengaruhi Keputusan Mahasiswa dalam Memilih Program Studi Manajemen Jenjang Strata-1 pada Perguruan Tinggi Swasta dan Perguruan Tinggi Negeri Di Kota Jambi

tabel 1,96. Artinya ekonomi berpengaruh dengan arah hubungan negatif namun tidak signifikan, sehingga hipotesis 17 ditolak. Artinya, kendatipun kemampuan ekonomi menurun, namun keputusan mahasiswa untuk kuliah pada prodi manajemen tetap meningkat, diasumsikan karena adanya kontribusi faktor lain yang mendukung sisi finansial mahasiswa, seperti: beasiswa. Hal tersebut relevan dengan program Pemerintah yang telah banyak membantu masyarakat khususnya dari taraf ekonomi yang tidak mampu, untuk bisa kuliah. Dengan beasiswa Bidikmisi, beasiswa Kartu Indonesia Pintar, bahkan beasiswa yang disediakan oleh Yayasan sebuah institusi, menjadikan masyarakat dari berbagai kalangan bisa meneruskan studinya ke jenjang yang lebih tinggi. Hasil temuan Paulsen dan St.John 2002 (dalam Wilkins et al., 2013), menyatakan bahwa korelasi yang kuat terjadi diantara keputusan calon mahasiswa dan status sosial ekonomi keluarga. Pihak institusi juga perlu memperhatikan aspek ekonomi dalam kebijakan marketing mix, dengan meningkatkan kuota penerima beasiswa sehingga putra-putri daerah yang berprestasi meskipun dari status sosial yang lemah, memiliki kesempatan yang sama untuk bisa melanjutkan studinya ke jenjang perguruan tinggi.

\section{Analisis dan Implikasi Pengaruh Sosial Terhadap Sikap}

Hasil pengujian diketahui bahwa nilai koefisien jalur parameter sosial terhadap sikap adalah sebesar 0,17 dengan nilai t-statistik 2,05 lebih tinggi dibandingkan t-tabel 1,96. Artinya faktor sosial berpengaruh secara langsung dengan arah hubungan positif signifikan, sehingga hipotesis 18 diterima. Hasil penelitian ini relevan dengan temuan dari Rumingsih et al., (2016); Saputra et al., (2015), yang menyatakan bahwa kelas sosial ekonomi yang mencakup profesi, tingkat pendapatan, tingkat pendidikan, maupun kekayaan yang dimiliki, cenderung mempengaruhi sikap mahasiswa. Hubungan positif yang ditunjukkan pada aspek sosial dalam kasus ini, menunjukkan bahwa semakin tinggi perhatian pihak institusi terhadap unsur pembentuk sosial yakni peran keluarga, alumni, teman sejawat, maka akan memberikan kontribusi dalam pembentukan sikap. Alma (2014) memberikan contoh selain dari mutu produk, bahwa kinerja alumni jurusan tertentu turut mempengaruhi preferensi mahasiswa. Dalam strategi marketing mix, pihak institusi dapat mengembangkan program tracer study, untuk membentuk sikap positif masyarakat, dengan informasi yang diperoleh terkait keberhasilan alumni tentunya akan memberikan motivasi, sehingga terbentuk persepsi yang mengarahkan kepada sikap positif masyarakat yang merupakan cerminan perilaku yang akan ditunjukkan.

\section{Analisis dan Implikasi Pengaruh Sosial Terhadap Keputusan Mahasiswa Melalui Sikap}

Hasil pengujian diketahui bahwa nilai koefisien parameter sosial terhadap keputusan mahasiswa yang dimediasi oleh sikap adalah sebesar 0,12 dengan nilai t-statistik 2,00 lebih tinggi dibandingkan t-tabel 1,96. Artinya faktor sosial berpengaruh secara tidak langsung dengan arah hubungan positif signifikan, sehingga hipotesis 19 diterima. Hasil temuan ini relevan dengan hasil penelitian Eravia (2012); (Rumingsih et al., (2016), namun berbeda dengan hasil temuan Harahap, 2015 (dalam Maknunah Lu'lu Ul, 2020). Peranan alumni dalam merekrut calon mahasiswa juga sangat penting, alumni merupakan indikator dari faktor sosial, demikian pengaruh yang diberikan orangtua, relevan dengan hasil penelitian Morris, 1977:612 (dalam Alma, 2014) bahwa paling efektif dengan orang tua calon siswa, Kotler,1976:68 (dalam Alma, 2014) juga menyatakan benefit yang diperoleh institusi, apabila mendapat dukungan yang kuat dari para alumni. Artinya institusi perlu membina hubungan yang baik dengan para alumni, dimana Institusi dapat memperoleh informasi yang berarti untuk mengembangkan institusinya, yakni melalui tracer study. Dikti, 2012 (dalam Nasuha \& Kondar Siahaan, 2016), bahwa melalui Tracer study diperoleh informasi, yang dibutuhkan untuk mengevaluasi jasa institusi, untuk penyempurnaan dan penjaminan kualitas institusi bersangkutan. Studi yang dilakukan oleh Nasuha \& Kondar Siahaan (2016), menyatakan bahwa cara yang dilakukan untuk mendata alumni yang masih bersifat manual dinilai kurang efektif, untuk itu adanya sistem informasi berbasis web yang dapat menjadi solusi. Hal tersebut relevan dengan konsep yang dinyatakan oleh Alma, (2014), bahwa kinerja alumni memiliki peran penting dalam menarik calon mahasiswa baru, sehingga alumni menjadi elemen penting yang mempengaruhi citra institusi. Selain itu perlu menjalin silahturahmi dengan para orangtua mahasiswa, dan mengembangkan prestasi mahasiswa tidak hanya dibidang akademis tetapi juga non akademis, karena program studi yang mampu menciptakan mahasiswa yang berprestasi menjadi referensi bagi calon mahasiswa lainnya. Chen \& Zimitat, 2006 (dalam Rudd et al.,2012), berpendapat bahwa keluarga memberikan pengaruh dalam proses pengambilan keputusan individu. Dalam hal ini, pihak institusi perlu mempertimbangkan faktor sosial dalam pengambilan keputusan bauran pemasaran.

\section{Analisis dan Implikasi Pengaruh Motivasi Terhadap Sikap}

Hasil pengujian diketahui bahwa nilai koefisien jalur untuk parameter motivasi terhadap sikap adalah sebesar 0,45 dengan nilai t-statistik 5,10 lebih tinggi dibandingkan t-tabel 1,96. Artinya motivasi berpengaruh secara langsung dengan arah hubungan positif signifikan, sehingga hipotesis 20 diterima. Neal Quester Hawkins (dalam Nitisusastro, 2012) menyatakan bahwa sikap merupakan perpaduan dari faktor internal individu, yakni; motivasi, emosi, persepsi dan proses kognitif, sebagai respon terhadap stimulus yang diterima atas suatu objek. Sebelum sikap terbentuk ada 
Friska Artaria Sitanggang, Dini Elida Putri dan Prayetno Agustinus Sitanggang, Analisis Faktor-Faktor yang Mempengaruhi Keputusan Mahasiswa dalam Memilih Program Studi Manajemen Jenjang Strata-1 pada Perguruan Tinggi Swasta dan Perguruan Tinggi Negeri Di Kota Jambi

tahapan yang dilalui oleh konsumen, yakni tahap pengenalan masalah, pada tahap ini proses psikologi internal yang terbentuk menurut Hasan (2013) adalah motivasi. Motivasi merupakan faktor yang menggerakkan seseorang untuk berperilaku. Merujuk pada butir pernyataan instrumen, terkait salah satu hal yang memotivasi mahasiswa adalah peningkatan dalam hal ketrampilan kewirausahaan yang menyatakan rata-rata tanggapan sebesar 4,38 (sangat setuju). Untuk itu, perlunya pihak institusi mengambil kebijakan yang mendukung peningkatan terhadap aspek motivasi, yakni dengan mengetahui hal-hal apa saja yang memotivasi mahasiswa, sehingga untuk program-program yang dijalankan mengarah kepada pembentukan sikap positif bagi calon mahasiswa.

\section{Analisis dan Implikasi Pengaruh Motivasi Terhadap Keputusan Mahasiswa Melalui Sikap}

Hasil pengujian diketahui bahwa nilai koefisien jalur untuk parameter motivasi terhadap keputusan mahasiswa yang dimediasi oleh sikap adalah sebesar 0,32 dengan nilai t-statistik 3,90 lebih tinggi dibandingkan t-tabel 1,96. Artinya motivasi berpengaruh tidak langsung dengan arah hubungan positif signifikan, sehingga hipotesis 21 diterima. Hasil temuan ini diperkuat dengan hasil temuan Erdawati, (2015); Miauw (2016). Erdawati (2015) menyatakan manfaat yang diperoleh apabila persepsi yang baik terbentuk pada suatu institusi, tentunya akan memberikan kesempatan bagi institusi tersebut untuk menarik banyak mahasiswa. Arah hubungan yang linear dalam kasus ini, mengindikasikan bahwa semakin tinggi motivasi maka akan semakin tinggi keputusan mahasiswa. Untuk itu perlunya dukungan dari pihak institusi dalam mengembangkan motivasi mahasiswa, dengan program atau kebijakan yang dapat berimplikasi positif terhadap peningkatan kuantitas dan kualitas mahasiswa.

\section{Analisis dan Implikasi Pengaruh Persepsi Terhadap Sikap}

Hasil pengujian diketahui bahwa nilai koefisien jalur untuk parameter persepsi terhadap sikap adalah sebesar 0,23 dengan nilai t-statistik 2,21 lebih tinggi dibandingkan t-tabel 1,96. Artinya persepsi berpengaruh langsung dengan arah hubungan positif signifikan, sehingga hipotesis 22 diterima. Hasil temuan ini diperkuat dengan hasil temuan dari Erdawati (2015). Persepsi merupakan proses psikologi yang berhubungan dengan pencarian informasi, setelah itu konsumen akan ketahapan evaluasi alternatif, dimana pada tahap ini terbentuk sikap (Hasan, 2013). Merujuk pada tanggapan responden dalam instrumen, bahwa responden memberikan persepsi yang baik terhadap program studinya dengan nilai rata-rata tanggapan 4 (setuju). Dalam hal ini perlunya pihak institusi meningkatkan persepsi positif masyarakat atau calon mahasiswa, untuk membentuk sikap yang positif terhadap sebuah program studi dalam suatu institusi.

\section{Analisis dan Implikasi Pengaruh Persepsi Terhadap Keputusan Mahasiswa}

Hasil pengujian diketahui bahwa nilai koefisien jalur parameter persepsi terhadap keputusan mahasiswa secara total adalah 0,31 dan secara langsung 0,14 dengan nilai t-statistik 2,78 lebih tinggi dibandingkan t-tabel 1,96. Artinya persepsi berpengaruh langsung dengan arah hubungan positif signifikan, sehingga hipotesis 23 diterima. Pernyataan tersebut diperkuat, dengan hasil penelitian Maknunah Lu'lu Ul (2020). Sumarwan, 2002 (dalam Ismanto, 2017), menyatakan pentingnya pemasar dalam memahami persepsi konsumen, agar dapat menyediakan produk maupun jasa yang relevan dengan ekspektasi konsumen. Untuk itu pihak manajemen institusi perlu meningkatkan persepsi masyarakat khususnya terhadap program studi yang ditawarkan, untuk menarik banyak mahasiswa baru.

\section{Analisis dan Implikasi Pengaruh Citra Perguruan Tinggi Terhadap Sikap}

Hasil pengujian diketahui bahwa nilai koefisien jalur untuk parameter citra perguruan tinggi terhadap sikap adalah sebesar 0,23 dengan nilai t-statistik 2,71 lebih tinggi dibandingkan t-tabel 1,96. Artinya citra perguruan tinggi berpengaruh langsung dengan arah hubungan positif signifikan, sehingga hipotesis 24 diterima. Hasil temuan ini diperkuat dengan hasil penelitian Sawaji (2019). Image mencerminkan pengetahuan seseorang terhadap suatu objek, yang terbentuk dari proses pengalaman dan pembelajaran (Suparto, 2014). Arah hubungan yang searah dalam kasus ini mengindikasikan bahwa, citra perguruan tinggi yang baik dari sebuah institusi akan meningkatkan sikap positif mahasiswa. Oleh sebab itu, pihak institusi perlu meningkatkan citra perguruan tingginya, yakni melalui proses pencapaian yang luar biasa dalam segala aspek bauran pemasaran yang dimiliki. Dengan terbentuknya image positif pada masyarakat melalui informasi-informasi yang telah diperoleh, tentunya akan menciptakan sikap positif masyarakat terhadap program studi maupun institusi.

\section{Analisis dan Implikasi Pengaruh Citra Perguruan Tinggi Terhadap Keputusan Mahasiswa Melalui Sikap}

Hasil pengujian diketahui bahwa nilai koefisien jalur untuk parameter citra perguruan tinggi terhadap keputusan mahasiswa yang dimediasi oleh sikap adalah sebesar 0,17 dengan nilai t-statistik 2,60 lebih tinggi dibandingkan ttabel 1,96. Artinya citra perguruan tinggi berpengaruh tidak langsung dengan arah hubungan positif signifikan, sehingga hipotesis 25 diterima. Hasil temuan tersebut diperkuat dengan hasil penelitian Sawaji (2019); (Rudd, 
Friska Artaria Sitanggang, Dini Elida Putri dan Prayetno Agustinus Sitanggang, Analisis Faktor-Faktor yang Mempengaruhi Keputusan Mahasiswa dalam Memilih Program Studi Manajemen Jenjang Strata-1 pada Perguruan Tinggi Swasta dan Perguruan Tinggi Negeri Di Kota Jambi

Djafarova dan Waring, 2012). Alma (2014) menyatakan bahwa citra tidak dapat dibentuk dengan mudah, akan tetapi citra adalah kesan yang diperoleh sesuai dengan pengetahuan dan pemahaman seseorang terhadap suatu objek. Citra terbentuk dari kualitas pelayanan yang diberikan oleh penyedia jasa, apabila konsumen merasa puas dengan layanan yang diterima, maka informasi yang disampaikan kepada masyarakat melalui word of mouth juga akan positif, sehingga terbentuk persepsi dan sikap positif masyarakat. Rata-rata nilai tanggapan responden terhadap citra perguruan tinggi yakni 4,14 (setuju), mengindikasikan penilaian mahasiswa yang positif baik terhadap layanan jasa maupun juga reputasi kampus.

\section{Analisis dan Implikasi Pengaruh Sikap Terhadap Keputusan Mahasiswa}

Hasil pengujian diketahui bahwa nilai koefisien jalur untuk parameter sikap terhadap keputusan mahasiswa adalah sebesar 0,72 dengan nilai t-statistik 8,31 lebih tinggi dibandingkan t-tabel 1,96. Artinya sikap berpengaruh langsung dengan arah hubungan positif signifikan, sehingga hipotesis 26 diterima. Hasil temuan ini diperkuat dengan hasil temuan Fauzie et al., (2016); Miauw (2016). Sikap diyakini mempunyai hubungan yang cukup erat dengan perilaku, ditunjukkan dengan nilai korelasi 72\%. Dalam hal ini pihak manajemen institusi perlu melakukan komunikasi persuasif, dalam upaya mengubah atau membentuk sikap positif masyarakat. Berdasarkan hasil pengujian, sikap positif ditunjukkan oleh responden, baik terhadap layanan program studi, ketertarikan mahasiswa terhadap program studi Manajemen, maupun prospek karir lulusan. Didukung oleh hasil rata-rata tanggapan 4,3 (sangat setuju), atas pernyataan yang diberikan. Proses yang terjadi dalam perilaku mahasiswa sebagai pengguna jasa pendidikan, merupakan proses yang saling berkaitan antara satu variabel dengan variabel lainnya, sehingga terbentuk sebuah keputusan. Faktor-faktor upaya pemasar memberikan suatu dorongan (motivasi) kepada masyarakat untuk masuk pada program studi yang ditawarkan, sehingga terbentuklah persepsi melalui pengetahuan serta pemahaman yang diterima, mengarah kepada pembentukan sikap. Hasil temuan menunjukan adanya pengaruh yang lebih besar dari variabel sikap, sehingga konstruk ini dapat dijadikan pertimbangan bagi institusi dalam merumuskan strategi pemasaran, dengan cara memberikan pengetahuan dan komunikasi persuasif, sehingga membentuk sikap tertarik kepada program studi yang ditawarkan, mengarah kepada keputusan penggunaan jasa pendidikan. Implikasi dari faktor-faktor yang mempengaruhi keputusan mahasiswa, adalah memberikan informasi penting bagi suatu institusi, terkait hal-hal yang memotivasi calon mahasiswa, sehingga dapat disusun strategi yang tepat melalui atribut produk yang dimiliki, baik itu kurikulum, prospek karir lulusan, kualitas tenaga dosen, mutu dan kualitas pelayanan yang diberikan dari berbagai aspek, guna mendukung terciptanya kualitas jasa sesuai dengan ekspektasi masyarakat.

\section{SIMPULAN}

Dalam penelitian ini dilakukan analisis, untuk mengetahui faktor-faktor apa saja yang mempengaruhi keputusan mahasiswa. Alur perilaku konsumen sebagaimana yang ditunjukkan oleh Hasan, (2013:165), bahwa konstruk program studi, lokasi, sarana prasarana, promosi, dan biaya merupakan stimulus pemasaran yang diberikan oleh pihak institusi, stimulus ini diterima oleh calon mahasiswa dari beragam karakteristik sosial maupun latar belakang ekonomi yang menjadi kontruk dalam riset ini. Berdasarkan hasil pengujian yang dilakukan dengan analisis SEM, diketahui bahwa faktor-faktor yang signifikan mempengaruhi keputusan mahasiswa, meliputi: faktor program studi $(0,10)$, citra perguruan tinggi $(0,17)$, faktor sosial $(0,12)$, motivasi $(0,32)$, sikap $(0,72)$, dan persepsi $(0,31)$. Konstruk yang memiliki pengaruh lebih besar terhadap keputusan mahasiswa adalah sikap. Melalui riset yang telah dilakukan diketahui pula faktor yang mempengaruhi citra perguruan tinggi yaitu program studi, serta faktor yang berpengaruh terhadap sikap yaitu program studi, citra perguruan tinggi, sosial, persepsi, dan motivasi.

Berdasarkan tanggapan responden, diketahui dari butir pernyataan bahwa rata-rata 4,33, merasa sangat puas dengan keputusan yang telah diambil untuk pilihan program studi Manajemen. Respon yang diberikan oleh mahasiswa, terhadap pelayanan jasa yang telah diberikan, menjadi umpan balik bagi institusi untuk merumuskan strategi pemasaran yang tepat, baik dalam penentuan segmentasi pasar, target pasar, positioning, maupun bauran pemasaran. Tantangan bagi setiap institusi, untuk dapat memberikan layanan yang yang baik kepada masyarakat khususnya mahasiswa sebagai penerima jasa pendidikan, guna menciptakan loyalitas mahasiswa terhadap kampus yang dikelola, dalam upaya mempertahankan dan meningkatkan kuantitas mahasiswanya mengarah kepada pencapaian visi dan misi, karena bukan tidak menutup kemungkinan, mahasiswa akan mengambil keputusan baru untuk beralih pada program studi maupun institusi lainnya. Berita negatif terkait institusi, dapat mempengaruhi citra institusi, agar image institusi tetap terjaga, maka harus sesegera mungkin diselesaikan, sebelum informasi tersebar dengan sangat mudah di era digital ini, sehingga merusak image institusi, dan untuk mengembalikan citra institusi membutuhkan waktu yang relatif lama. Oleh karena itu, program studi dapat melakukan komunikasi persuasif dengan memberikan informasi positif kepada masyarakat, untuk menciptakan image dan persepsi yang positif terhadap institusi yang dikelola. 
Friska Artaria Sitanggang, Dini Elida Putri dan Prayetno Agustinus Sitanggang, Analisis Faktor-Faktor yang Mempengaruhi Keputusan Mahasiswa dalam Memilih Program Studi Manajemen Jenjang Strata-1 pada Perguruan Tinggi Swasta dan Perguruan Tinggi Negeri Di Kota Jambi

\section{DAFTAR PUSTAKA}

Alma, B. 2014. Manajemen Pemasaran dan Pemasaran Jasa. Edisi Kesebelas. Alfabeta. Bandung.

Eravia, D. 2012. Analisis Keputusan Mahasiswa Memilih International Class UIN SUSKA Riau Sebagai Tempat Melanjutkan Pendidikan Pendahuluan. Kutubkhanah: Jurnal Penelitian Sosial Keagamaan 15(1): 12-26.

Erdawati. 2015. Pengaruh Motivasi, Persepsi, dan Promosi Terhadap Keputusan Mahasiswa Memilih STIE Pasaman Simpang Empat. Jurnal Apresiasi Ekonomi 2(3): 153-159.

Fauzie, D., Yulianto, E., \& Sunarti, S. 2016. Pengaruh Faktor Psikologis Konsumen Terhadap Keputusan Pembelian (Survei Pada Konsumen KFC Cabang Mall Olympic Garden Malang). Jurnal Administrasi Bisnis S1 Universitas Brawijaya 40 (1): 1-7.

Fitriani, N. 2018. Peran Kualitas Pelayanan dan Kepuasan Pelanggan Dalam Pembentukan Word of Mouth Mahasiswa Perguruan Tinggi Swasta di Jakarta. Jurnal Manajemen Indonesia.

Hamid, Rahmad Solling, dan S. M. A. 2019. Structural Equation Modeling (SEM) Berbasis Varian. PT Buku Seru.Jakarta.

Hasan, A. 2013. Marketing dan Kasus-Kasus Pilihan. PT Buku Seru.Jakarta.

Ismanto, J. 2017. Analisis Pengaruh Persepsi Mahasiswa Pada Unsur-Unsur Bauran Pemasaran Terhadap Keputusan Mahasiswa Memilih Perguruan Tinggi IPWIJA Program S2 (Pasca sarjana). Econosains: Jurnal Online Ekonomi dan Pendidikan 15(1): 125-143.

Kusuma, C. K. 2015. Pengaruh Sikap Konsumen Terhadap Marketing Mix Hospitality. Telaah Bisnis 16(2): 73-84.

Maknunah Lu'lu Ul, F. S. 2020. Pengaruh motivasi, pembelajaran, persepsi dan sikap terhadap keputusan mahasiswa memilih jurusan. Jurnal Reformasi 10(1): 11-18.

Miauw, K. Y. H. 2016. Motivasi Konsumen Dan Sikap Konsumen Terhadap Keputusan Pembelian Di Wild. Jurnal Manajemen dan Start-Up Bisnis.

Muchammad, Bima Nur, R. R. 2014. Pengaruh Marketing Mix Keputusan Memilih Studi Mahasiswa. Jurnal Bisnis Indonesia 5(1): 54-66.

Nasuha, A., \& Kondar Siahaan2. 2016. Analisis Dan Perancangan Sistem Informasi Alumni (Tracer Study) Berbasis Web Pada Iain Sulthan Thaha Saifuddin Jambi. Jurnal Manajemen Sistem Informasi Vol 1 No. 1, September 2016 ISSN : 2540-8011.

Nitisusastro, M. 2012. Perilaku Konsumen Dalam Pespektif Kewirausahaan. Alfabeta.Bandung., 2012.

Podungge, E. S., \& Bachri, S. 2015. STMIK Bina Mulia Palu. Jurnal Katalogis 3(10): 59-70.

Prasetyaningrum, I. D. 2016. Pengaruh Kinerja Bauran Pemasaran Jasa Pendidikan Terhadap Citra Universitas (Studi Kasus Pada Fakultas Ekonomi Universitas Muria Kudus. Prosiding Seminar Nasional Multi Disiplin Ilmu \& Call for Papers Unisbank (Sendi_U), 2, 666-680.

Purwanti, E. 2015. Analisis Faktor-Faktor Pengambilan Keputusan Mahasiswa Memilih Stie "Ama" Salatiga. AMA Salatiga 8(6): 40-54.

Ramadhanti, D., Mulyadi, H., \& Razati, G. 2017. Pengaruh Status Sosial Ekonomi Orang Tua Terhadap Sikap Kewirausahaan. Strategic : Jurnal Pendidikan Manajemen Bisnis. https://doi.org/10.17509/strategic.v16i2.7068

Rudd, B., Djafarova, E., \& Waring, T. 2012. Chinese students' decision-making process: A case of a Business School in the UK. International Journal of Management Education. https://doi.org/10.1016/j.ijme.2012.04.001

Rumingsih, Baiq Diyah, Etty Soesilowati, dan J. W. 2016. Peran Sikap Konsumen Dalam Memediasi Pengaruh Lingkungan Sosial dan Pengetahuan Ekonomi Terhadap Perilaku Konsumsi Siswa. Journal of Economic Education 5(2): 193-205.

Samat, Marnisah, L., Hendro, O., \& Jenahar, T. 2018. Bauran Pemasaran Terhadap Keputusan Mahasiswa Memilih Perguruan Tinggi Swasta di kota Palembang. Jurnal Manajemen Dan Bisnis Sriwijaya 15(4): 221-229.

Saputra, U. D., Aminuyati, \& Utomo, B. B. 2015. Pengaruh Kelas Sosial Dan Rasionalitas Ekonomi Terhadap Perilaku Konsumsi Mahasiswa Pendidikan Ekonomi FKIP Untan. Jurnal Pendidikan dan Pembelajaran Khatulistiwa 4(6): 1-16.

Sarwono, J., \& Narimawati, U. 2020. Membuat Skripsi, Tesis, dan Disertasi dengan Partial Least Square SEM (PLSSEM). Penerbit Andi.

Sarwono, Y. 2010. Pengertian Dasar Structural Equation Modeling (SEM). Jurnal Ilmiah Manajemen Bisnis Ukrida.

Sawaji, J. 2019. Dampak Citra Perguruan Tinggi Guna Meningkatkan Motivasi, Sikap, dan Pengambilan Keputusan Mahasiswa Memilih PTS di Sulawesi Selatan. Jurnal Manajemen Bisnis 6(2): 69-76.

Suherman. 2017. Analisis Pengaruh Bauran Pemasaran Terhadap Keputusan Mahasiswa Memilih Kuliah di IAIN Parepare. Al-Buhuts Jurnal Ekonomi Islam 13(2): 18-38.

Sunyoto, D. 2015. Perilaku Konsumen dan Pemasaran. Center of Academic Publishing Service.Yogyakarta.

Suparto. 2014. Analisis Korelasi Varibel-variabel yang Mempengaruhi Siswa dalam Memilih Perguruan Tinggi. JUrnal IPTEK. 
Friska Artaria Sitanggang, Dini Elida Putri dan Prayetno Agustinus Sitanggang, Analisis Faktor-Faktor yang Mempengaruhi Keputusan Mahasiswa dalam Memilih Program Studi Manajemen Jenjang Strata-1 pada Perguruan Tinggi Swasta dan Perguruan Tinggi Negeri Di Kota Jambi

Wilkins, S., Shams, F., \& Huisman, J. 2013. The decision-making and changing behavioural dynamics of potential higher education students: the impacts of increasing tuition fees in England. Educational Studies. https://doi.org/10.1080/03055698.2012.681360 